\title{
Sistematik Numerik Strain-Strain Anggota Genus Pseudomonas Pendegradasi Alkilbenzen Sulfonat Liniar Berdasarkan Sifat Fenotip dan Protein Fingerprinting
}

\section{Numerical Systematics of Linear Alkylbenzene Sulphonate-Degrading Pseudomonas Strains Based on Phenotype Character and Protein Fingerprinting}

\author{
Suharjono $^{1 *}$, Langkah Sembiring ${ }^{2}$, Jusup Subagja², Tri Ardyati ${ }^{1}$, Lisa Lisdiana ${ }^{1}$ \\ 1. Jurusan Biologi, FMIPA, Universitas Brawijaya, Malang \\ E-mail: calistus@brawijaya.ac.id *Penulis untuk korespondensi \\ 2. Fakultas Biologi, Universitas Gadjah Mada, Yogyakarta
}

\begin{abstract}
Bacteria strains consisting of Pseudomonas sp. strain $\mathbf{J}$ and $\mathbf{R}$ isolated from river ecosystem polluted and Pseudomonas sp. strain A and B isolated from river ecosystem unpolluted by detergent were capable to degrade of LAS. The objective of this research was to determine similarity value by numerically of LAS-degrading Pseudomonas strains based on phenotype character and protein fingerprinting using three reference strains consist of Pseudomonas putida FNCC071, P. fluorescens FNCC070, and P. aeruginosa FNCC063. Phenotype characteristics examined are cellular and colony morphology, biochemical nature, capability to degrade polysaccharide, tolerance to various environmental factors and antibiotics, and ability to ferment sugar. Cellular protein fingerprinting was analyzed using SDS-PAGE discontinuous. Strains classification was determined based on Simple Matching Method similarity index by UPGMA (Unweight Pair Group Method with Average) algorithm. Based on phenotype nature, all strains have similarity value 0.61; however, based on cellular protein fingerprinting, those strains have similarity value 0.52 . All strains of LAS-degraded were including in the genus of Pseudomonas.
\end{abstract}

Key words: Pseudomonas strains, phenotype character, numerical systematic, protein fingerprinting, similarity

Diterima: 05 Oktober 2006, disetujui: 28 Februari 2007

\section{Pendahuluan}

Linear Alkilbenzen Sulfonat (LAS) merupakan surfaktan anionik yang dominan digunakan dalam formulasi deterjen sintetik (Schoberl, 1989; Jimenez et al., 1991; CamposGarcia et al., 1999; Jerabkova et al., 1999; Scleheck et al., 2003). Senyawa tersebut saat ini merupakan pencemar utama ekosistem sungai di berbagai kota besar Asia Tenggara (Siguilot dan Nguyen, 1992; Retnaningdyah et al., 1999; Kenzaka et al., 2001). Konsentrasi residu LAS di ekosistem sungai yang sudah melampaui nilai baku $0,5 \mathrm{mg} / \mathrm{L}$ bersifat toksik terhadap berbagai organisme akuatik (Zeni dan
Caligiuri 1992; Retnaningdyah et al., 1999 dan 2001). Konsentrasi dan toksisitas residu LAS tersebut dapat direduksi dengan proses biodegradasi menggunakan aktivitas bakteri. Berbagai strain bakteri anggota Genus Pseudomonas kelimpahannya predominan dan tersebar luas di ekosistem alami serta berperan dominan dalam mendegradasi senyawa LAS tersebut (Horn et al., 1991; Jimenez et al., 1991; Galli et al., 1992; Van Ginkel, 1996; Campos-Garcia et al., 1999; Jerabkova et al., 1999; Kahnert et al., 2000; Wackett, 2003; Suharjono et al., 2004).

Dua strain yaitu Pseudomonas sp. strain J dan R, isolat dari ekosistem Sungai Sawojajar I Kota Malang yang tercemar deterjen, mampu 
mendegradasi LAS secara berturut-turut sebesar 52,67\% dan 48,9\% dalam waktu empat hari. Dua strain lain yaitu Pseudomonas sp. strain A dan B, isolat dari ekosistem Sungai Sumbersekar Kabupaten Malang yang tidak tercemar deterjen, mampu mendegradasi senyawa tersebut secara berturut-turut sebesar $41,4 \%$ dan $46,1 \%$ dalam waktu sembilan hari. Strain-strain anggota genus yang sama tersebut dan berasal dari ekosistem sungai yang berbeda menunjukkan kemampuan biodegradasi yang berbeda terhadap LAS (Suharjono et al., 2004). Penelitian ini bertujuan untuk mempelajari lebih mendalam mengenai klasifikasi strainstrain pendegradasi LAS tersebut secara numerik berdasarkan sifat fenotip dan profil pita protein selular menggunakan algoritma UPGMA (Unweight Pair Group Method with Average). Sistem klasifikasi ini diharapkan dapat memberikan diskripsi yang baik dan obyektif dari strain-strain tersebut.

\section{Metode Penelitian}

\section{Strain-strain bakteri uji}

Isolat bakteri yang digunakan dalam penelitian ini meliputi tiga strain dari ekosistem Sungai Sawojajar I Kota Malang yang tercemar deterjen (Pseudomonas sp. strain $\mathbf{J}, \mathrm{J}_{\text {duplo }}$, dan $\mathrm{R})$, dua isolat dari ekosistem Sungai Sumbersekar Kabupaten Malang yang tidak tercemar deterjen (Pseudomonas sp. strain A dan B) serta tiga strain acuan yaitu Pseudomonas putida FNCC071, P. fluorescens FNCC070, dan $P$. aeruginosa FNCC063. Semua strain tersebut dibiakkan dalam medium Pseudomonas Agar $F$ Base yang diberi suplemen CFC (Cetrimide Fucidine Cephaloridine) dan mengandung $10 \mathrm{mg} / \mathrm{L}$ LAS.

\section{Karakterisasi sifat fenotip bakteri}

Identifikasi strain bakteri dengan pendekatan sistematik fenetik dilakukan berdasarkan karakterisasi sifat fenotip secara konvesional menurut Skinner dan Lovelock (1979) serta Collins et al., (1989). Ciri-ciri fenotip bakteri yang diamati meliputi karakter morfologi koloni dan sel, sifat biokimia, kemampuan biodegradasi, toleransi terhadap berbagai kondisi lingkungan, resistensi terhadap antibiotik, dan pemanfaatan berbagai sumber karbon. Ciri-ciri morfologi koloni yang diamati adalah pigmentasi medium dan koloni, bentuk dan diameter koloni serta kemampuan membentuk biofilm, sedangkan morfologi sel yang diamati meliputi bentuk, panjang, dan diameter sel serta reaksi pewarnaan Gram dan pembentukan endospora. Sifat biokimia strain-strain uji yang dikarakterisasi meliputi motilitas sel, reaksi katalase, koagulase, oksidase, DN-ase, Methyl Red, Voges Proskauer, reduksi nitrat, pembentukan indol, fermentasi susu, hidrolisis kasein, reaksi BGLB, produksi levan, Czapek Dox, pembentukan ammonia, pencairan gelatin, hidrolisis urea dan reaksi simon sitrat, metabolisme dalam media LIA, TSIA, dan SSS. Sifat potensi biodegradasi yang diuji yaitu biodegradasi terhadap amilum, lignin, selulosa, dan ABS. Karakter kemampuan metabolisme menggunakan sumber karbon yang diamati antara lain terhadap senyawa sorbitol, arabinosa, manosa, fruktosa, xylosa, galaktosa, laktosa, manitol, glukosa, sukrosa, dekstrosa, sakarosa, maltosa, ribosa, rhamnosa, melibiosa, dan trehalosa. Sifat-sifat fisiologis strain bakteri yang dikarakterisasi adalah resistensi terhadap antibiotik trimethropim, erythromycin, tetracyclin, chloramphenicol, kanamycin, clarithromycin, cephazolin, ampicilin, aztreonam, azithromycin, apramycin, clindamycin, dan cinoxacin; serta kemampuan tumbuh pada $\mathrm{pH} \mathrm{4,} \mathrm{7,} \mathrm{dan} \mathrm{9;}$ pertumbuhan pada media dengan $\mathrm{NaCl} 0,5,3$, dan $6 \%$; pertumbuhan pada suhu $10,30,42$, dan $60^{\circ} \mathrm{C}$.

\section{Karakterisasi profil protein bakteri}

Identifikasi strain-strain tersebut dengan pendekatan sistematik kimiawi dilakukan berdasarkan analisis sidik jari protein (protein fingerprinting) menurut metode Zarnowski et al., (2001). Protein yang dianalisis berupa total protein selular dengan menggunakan SDSPAGE (Sodium Dodecyl Sulphate Poly Acrilamide Gel Electrophoresis). Setiap strain dari biakan stok diremajakan ke dalam medium Nutrien Agar yang mengandung $10 \mathrm{mg} / \mathrm{L}$ LAS kemudian diinkubasikan $30^{\circ} \mathrm{C}$ selama 18 jam. 
Koloni setiap biakan strain tersebut diambil satu ose penuh dan diinokulasikan ke dalam medium Luria Bertani cair $\mathrm{pH}$ 7,0 serta diinkubasikan secara aerobik dalam inkubator rotary shaker pada kecepatan $120 \mathrm{rpm}$, suhu $30^{\circ} \mathrm{C}$ selama tiga hari. Suspensi biakan setiap strain disentrifugasi pada $10.000 \mathrm{rpm}, 4^{\circ} \mathrm{C}$ selama lima menit. Pelet sel dicuci dengan akuades steril kemudian disentrifugasi kembali. Pelet sel ditambah dengan inhibitor protease phenyl-methane-sulfonyl-fluoride satu milimolar dengan perbandingan 1:1 untuk mencegah aktivitas protease.

Pelet yang diperoleh dipanaskan dalam penangas air $39^{\circ} \mathrm{C}$ selama dua menit kemudian didinginkan $0^{\circ} \mathrm{C}$ selama 20 menit. Pelet sel tersebut disentrifugasi $10.000 \mathrm{rpm}$ pada $4^{\circ} \mathrm{C}$ selama lima menit, kemudian disuspensikan dengan $200 \mu \mathrm{l}$ reagen pelisis sel Cell lytic ${ }^{T M}$ BII Bacterial Cell Lysis/Extraction Reagent (Sigma). Suspensi kemudian diinkubasikan 20 menit pada suhu ruang, selanjutnya disentrifugasi lagi $10.000 \mathrm{rpm}$ pada $4^{\circ} \mathrm{C}$ selama lima menit. Supernatan disimpan dalam tabung Eppendorf yang baru sebagai sampel protein ekstrak sel bebas debris sel. Sampel tersebut diukur kadar proteinnya dengan metode Biuret menurut Burden dan Whitney (1995).

Sampel protein dianalisis menggunakan $S D S-P A G E$ dengan panjang gel $80 \mathrm{~mm}$ dan ketebalannya $1,5 \mathrm{~mm}$. Gel yang digunakan adalah gel discontinuous yang terdiri atas lima persen stacking gel dan 10\% separating gel. Sampel sebanyak $25 \mu \mathrm{l}$ diambil dengan Hamilton syringe kemudian dimasukkan ke dalam sumuran gel. Protein acuan yang digunakan adalah Lactate Dehydrogenase 35 $\mathrm{kDa}$, Ovalbumine $45 \mathrm{kDa}$, Bovine serum albumine 66,2 kDa, dan beta galaktosidase 116 $\mathrm{kDa}$.

Sampel dalam gel tersebut dielektroforesis pada suhu ruang dengan arus $20 \mathrm{~mA}$. Gel selanjutnya dicuci dengan campuran isopropanol, asam asetat, dan akuades dengan perbandingan 1:3:6 selama 30 menit, setelah itu dicuci dengan campuran methanol, asam asetat, dan akuades pada perbandingan 3:1:6 selama lima menit. Gel kemudian diwarnai dalam satu persen (w/v) Coomassie Brilliant Blue R-250 selama tiga jam. Warna dalam gel kemudian dilakukan destaining menggunakan Biota Vol. 12 (1), Februari 2007 campuran larutan methanol, asam asetat, dan akuades pada perbandingan 3:1:6, sampai pita protein terlihat jelas. Masing-masing pita protein dalam gel dari setiap strain bakteri ditentukan berat molekulnya dengan mengukur mobilitas molekul protein dalam gel poliakrilamid berdasarkan kurva baku berat molekul dari protein acuan.

Profil karakter fenotip dan profil sidik jari total protein antarstrain bakteri kemudian dianalisis secara numerik untuk mengetahui nilai similaritasnya. Hasil uji setiap unit karakter yang positif diberi tanda plus (+) sedangkan unit karakter yang negatif diberi tanda minus (-). Data karakter untuk fenotip atau protein yang telah diberi nilai dimasukkan ke dalam komputer dengan menggunakan program Excell. Data yang memiliki nilai $(+)$ diubah menjadi 1 dan nilai (-) menjadi 0. Data ini kemudian diolah menggunakan program CLAD97 (Rahardi, 2002) untuk mengonstruksikan fenogram yang mencerminkan indeks similaritas antarstrain menggunakan algoritma pengklasteran average linkage (UPGMA: Unweight Pair Group Methode with Arithmatic Average). Nilai similaritas ditentukan dengan metode Simple matching Method $\left(\mathrm{SS}_{\mathrm{M}}\right)$ menurut Sneath (1957 cit. Sembiring, 2002).

\section{Hasil dan Pembahasan}

Nilai similaritas paling tinggi berdasarkan sifat fenotipnya (Gambar 1) yaitu 0,99 antara Pseudomonas sp. strain J dengan $\mathrm{J}_{\text {duplo. Kedua strain tersebut berasal dari satu }}$ koloni yang dibiakkan secara terpisah. Oleh karena itu kedua isolat tersebut dapat dikatakan satu strain. Kedua isolat tersebut berbeda karena Pseudomonas sp. strain J resistensinya intermedier sedangkan Pseudomonas sp. strain $\mathrm{J}_{\text {duplo }}$ peka terhadap antibiotik Azithromycin (AZM15).

Pseudomonas sp. strain A dan B secara fenotipik memiliki nilai similaritas 0,90 . Kedua strain tersebut berbeda pada kemampuan Pseudomonas sp. strain A menghasilkan pigmen tidak berfluoresen dan koloni tidak berpigmen sedangkan Pseudomonas sp. strain B menghasilkan pigmen berfluoresen yang 
terdifusi ke dalam medium Pseudomonas Agar $F$ Base dan koloni berpigmen. Pseudomonas sp. strain A tersebut juga memiliki sifat tidak mampu menghidrolisis kasein, tidak menghasilkan levan dari sukrosa, mampu mendegradasi lignin dan ABS, sedangkan Pseudomonas sp. strain B memiliki sifat sebaliknya. Sifat fenotip lainnya yang berbeda yaitu Pseudomonas sp. strain A mampu memfermentasikan arabinosa dan galaktosa menghasilkan asam tanpa gas, tidak memfermentasikan xylosa, responnya intermedier terhadap kanamycin dan mampu tumbuh pada $42^{\circ} \mathrm{C}$; sedangkan Pseudomonas sp. strain B tidak memfermentasikan arabinosa dan galaktosa, memfermentasikan xylosa menghasilkan asam tanpa gas, peka terhadap kanamycin dan tidak tumbuh pada $42^{\circ} \mathrm{C}$. Kedua strain tersebut memiliki nilai similaritas 0,77 terhadap Pseudomonas sp. strain $\mathrm{J}$ dan $\mathbf{J}_{\text {duplo. }}$ Perbedaan fenotip kedua kelompok tersebut yaitu kelompok Pseudomonas sp. strain A dan B tidak mereduksi nitrat dan mampu menggunakan sitrat, sedangkan kelompok strain $\mathbf{J}$ memiliki sifat sebaliknya.

Kelompok pertama tersebut juga memiliki sifat memfermentasikan manosa dan glukosa menghasilkan asam tanpa gas, dan memfermentasikan sukrosa, maltosa, rhamnosa, melibiosa, dan trehalosa menghasilkan basa tanpa gas; sedangkan strain $\mathbf{J}$ dan $\mathbf{J}_{\text {duplo }}$ tidak memfermentasikan manosa, rhamnosa, dan melibiosa, memfermentasikan glukosa menghasilkan basa tanpagas,memfermentasikan sukrosa, maltosa, dan trehalosa menghasilkan asam tanpa gas. Sifat fenotip lainnya pada kelompok pertama yang berbeda dari kelompok kedua yaitu responnya intermedier terhadap tetracyclin dan apramycin serta resisten terhadap clarithromycin, cephazolin, aztreonam, azithromycin, dan cinoxacin, sedangkan kelompok Pseudomonas sp. strain J dan $\mathbf{J}_{\text {duplo }}$ peka terhadap tetracyclin, aztreonam, apramycin, dan cinoxacin; responnya intermedier terhadap clarithromycin dan cephazolin, serta responnya peka atau intermedier terhadap azithromycin.

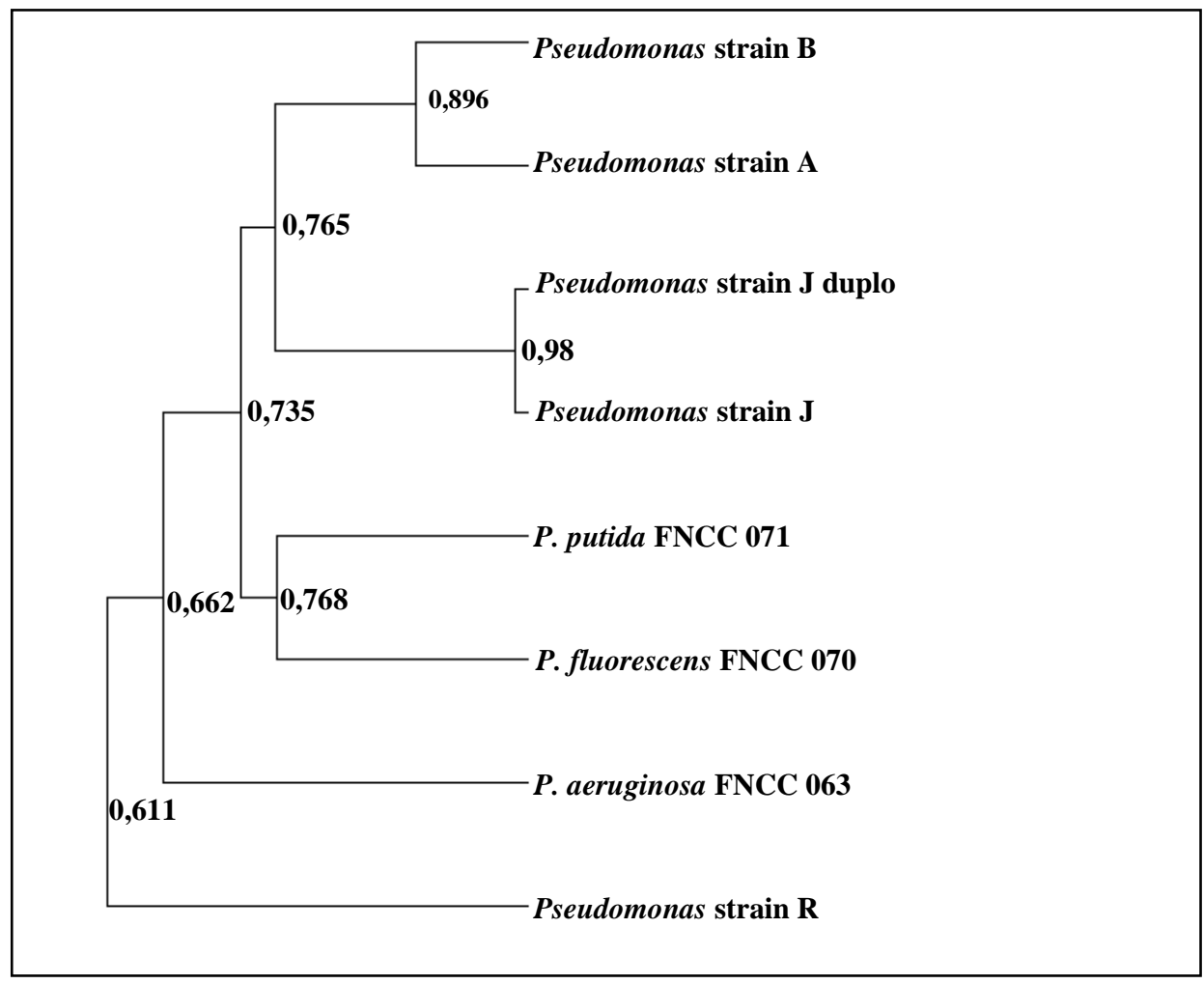

Gambar 1. Fenogram tingkat similaritas delapan strain anggota Genus Pseudomonas berdasarkan sifat fenotip 
Dua strain acuan yaitu $P$. fluorescens FNCC070 dan $P$. putida FNCC071 memiliki nilai similaritas 0,68 . Kelompok kedua strain tersebut secara fenotopik memiliki nilai similaritas $\quad 0,73$ terhadap kelompok Pseudomonas sp. strain A, B , J, dan $\mathrm{J}_{\text {duplo }}$; sedangkan $P$. aeruginosa FNCC063 terhadap kelompok besar tersebut memiliki nilai similaritas 0,66. Pseudomonas sp. strain R memiliki sifat fenotip yang paling berbeda di antara delapan strain uji, yaitu nilai similaritasnya 0,61 (paling rendah) terhadap kelompok tujuh strain uji lainnya.

Berdasarkan similaritas pita protein selular (Gambar 2 dan 3), menunjukkan bahwa Pseudomonas sp. strain $\mathrm{J}$ dan $\mathrm{J}_{\text {duplo }}$ juga memiliki kemiripan paling tinggi yaitu 0.97. Dari 77 macam protein yang diuji, Pseudomonas sp. strain $\mathrm{J}$ tidak memiliki protein 89,31 dan $134,13 \mathrm{kDa}$, sedangkan Pseudomonas sp. strain $\mathrm{J}_{\text {duplo }}$ memiliki kedua protein tersebut. $P$. putida FNCC071 dan $P$. fluorescens FNCC070 memiliki nilai similaritas 0,71 ; yaitu keduanya memiliki protein 24,0, 35,0, 39,17, 44,87, 52,47, 66,20, dan $66,34 \mathrm{kDa}$. Macam-macam protein yang membedakan kedua strain tersebut adalah protein $25,15,28,50,30,35,31,8,39,59,41,49$, $48,52,55,85,59,46,61,35,77,58$, dan 83,89 kDa dimiliki oleh $P$. putida FNCC071 tetapi tidak dimiliki oleh $P$. fluorescens FNCC070. Protein 27,63, 42,15, 49,28, 56,74, 58,54, 60,4, $63,3,74,02,85,21$, dan $92,14 \mathrm{kDa}$ dimiliki oleh $P$. fluorescens FNCC070 tetapi tidak dimiliki oleh $P$. putida $\mathrm{FNCC071.} P$. aeruginosa FNCC063 lebih mirip dengan kedua strain tersebut dibandingkan dengan strain-strain uji lainnya, dengan nilai similaritas 0,68 . Proteinprotein yang dimiliki oleh $P$. putida FNCC071 dan $P$. fluorescens FNCC070 tetapi tidak dimiliki oleh $P$. aeruginosa FNCC063 yaitu protein $35,0,44,87,52,47,66,2$, dan 66,34 $\mathrm{kDa}$; sedangkan protein 24,0 dan $37,19 \mathrm{kDa}$ dimiliki oleh ketiga strain tersebut.

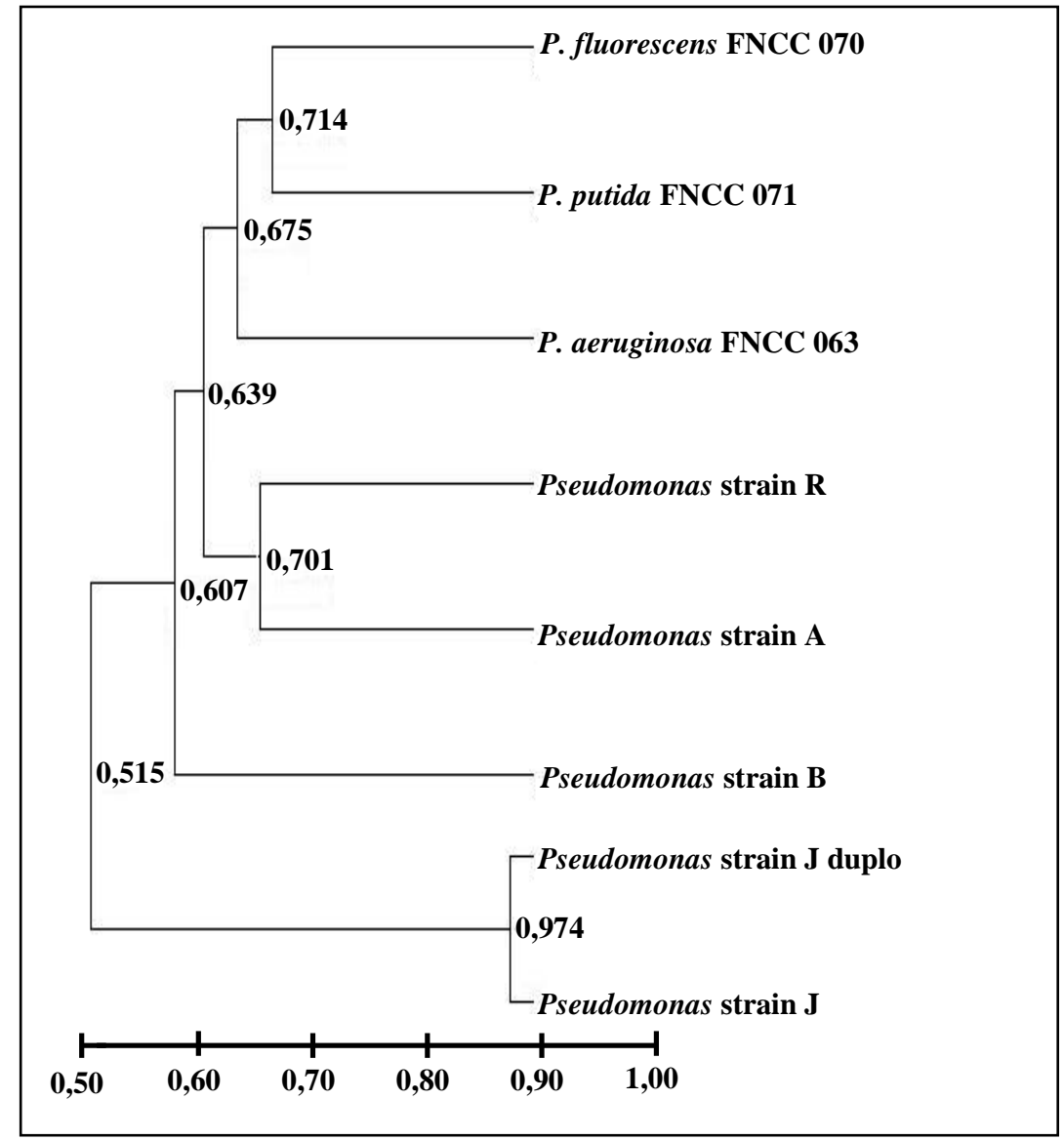

Gambar 2. Fenogram tingkat similaritas delapan strain anggota Genus Pseudomonas berdasarkan sidik jari protein selular 
Pseudomonas sp. strain $\mathrm{R}$ memiliki nilai similaritas karakter protein selularnya sebesar 0,701 terhadap Pseudomonas sp. strain A. Kedua strain tersebut berbeda karena Pseudomonas sp. strain $\mathrm{R}$ memiliki protein 24,0, 27,63, 28,95, 31,31, 32,81, 34,39, 37,78, 39,59 , 57,63, dan 89,31 kDa, sedangkan Pseudomonas sp. strain A tidak memiliki protein-protein tersebut tetapi memiliki protein dengan berat molekul 23,63, 25,15, 29,87, $32,30,35,48,38,37,49,28,54,13,58,54,67,39$, 71,74 , 90,71, dan 154,4 kDa. Kedua strain tersebut memiliki protein $42,15,44,17,52,47$, 62,32, 78,8, 83,89, dan 95,07 kDa.

Kelompok dua strain tersebut memiliki nilai similaritas 0,64 dengan kelompok ketiga strain acuan. Protein-protein yang dimiliki oleh kelompok tersebut tetapi tidak dimiliki oleh strain acuan yaitu protein $44,17,62,32$, dan 95,07 kDa. Pseudomonas sp. strain B memiliki similaritas sifat protein selular 0,61 terhadap kelompok kedua strain tersebut dan ketiga strain acuan, serta protein 40,21, 47,77, 51,65, $81,31,86,56,101,21,130,0$, dan 138,39 kDa hanya dimiliki oleh strain tersebut. Kelompok bakteri Pseudomonas sp. strain $\mathrm{J}$ dan $\mathrm{J}_{\text {duplo }}$ ternyata memiliki similaritas terendah sebesar 0,515 terhadap strain-strain lainnya.

Berdasarkan karakter protein selular, ternyata setiap klaster strain bakteri tersebut memiliki protein spesifik. Kelompok $P$. putida
FNCC071 dan $P$. fluorescens FNCC070 memiliki protein 44,87 dan 66,34 $\mathrm{kDa}$, sedangkan $P$. aeruginosa FNCC063 memiliki protein 34,93, 45,58, dan 52,44 $\mathrm{kDa}$. Kelompok Pseudomonas sp. strain $\mathrm{R}$ dan Pseudomonas sp. strain A memiliki protein spesifik 62,32 dan 95,07 $\mathrm{kDa}$, sedangkan Pseudomonas sp. strain B memiliki protein spesifik 40,21, 47,77; 81,31, dan 138,39 kDa. Pseudomonas sp. strain $\mathrm{J}$ dan $\mathrm{J}_{\text {duplo }}$ memiliki protein yang khas yaitu $24,76,26,36,30,82$, $36,61,38,98,65,31,72,87,82,59,96,57,116,0$, 120,22 , dan $125,99 \mathrm{kDa}$.

Berdasarkan sifat fenotip dan karakter protein selular masing-masing strain uji, menunjukkan bahwa $P$. putida FNCC071 dan $P$. fluorescens FNCC070 memiliki nilai similaritas lebih tinggi dibandingkan terhadap $P$. aeruginosa FNCC063, serta ketiga strain tersebut berada dalam satu kelompok. Hasil ini sesuai sistem klasifikasi berdasarkan kekerabatan 16S rDNA menurut Todar (2004). Sistem klasifikasi berdasarkan pendekatan fenotipik dan protein selular tersebut memberikan hasil yang berbeda. Hal ini disebabkan karakter-karakter fenotip setiap strain uji yang diamati belum mencakup seluruhnya. Berdasarkan sistem klasifikasi secara numerik ini, semakin banyak karakter yang diuji maka hasilnya semakin baik.

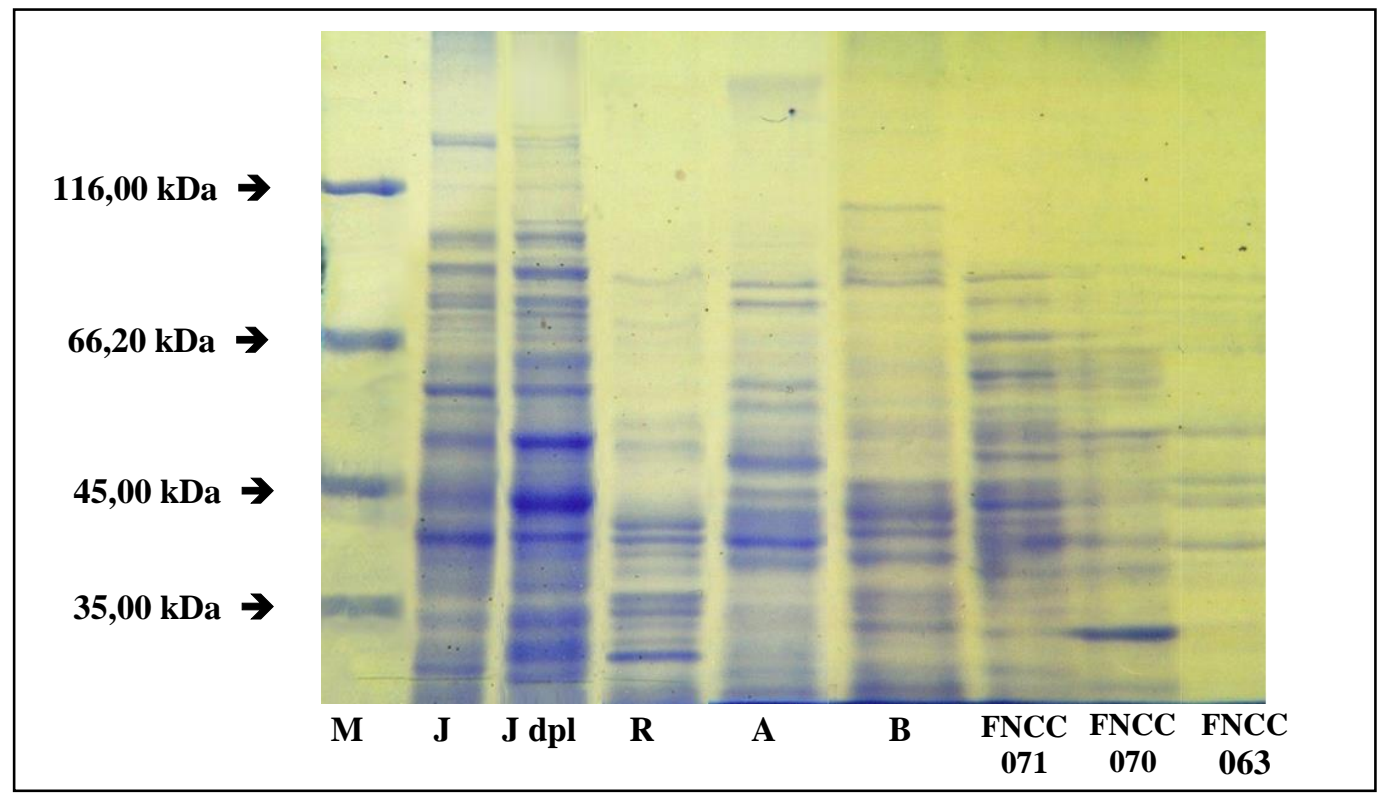

Gambar 3. Pola pita protein selular strain-strain bakteri anggota Pseudomonas hasil Elektroforesis $S D S$ PAGE 
Berdasarkan sifat fenotipnya, Pseudomonas sp. strain A memiliki kemiripan yang tinggi dan satu kelompok dengan Pseudomonas sp. strain B, tetapi berdasarkan karakter protein selularnya kedua strain tersebut tidak dalam satu kelompok. Berdasarkan sistem klasifikasi yang pertama tersebut, Pseudomonas sp. strain $\mathrm{R}$ paling rendah nilai similaritasnya terhadap strainstrain yang lain; tetapi berdasarkan sifat protein, kelompok Pseudomonas sp. strain $\mathbf{J}$ dan $\mathbf{J}_{\text {duplo }}$ yang memiliki similaritas terendah terhadap strain lainnya. Sistem klasifikasi secara numerik berdasarkan protein fingerprinting ternyata lebih efisien, obyektif, dan handal dibandingkan berdasarkan sifat fenotip. Berdasarkan konsep spesies, semua strain uji tersebut merupakan anggota Genus Pseudomonas karena memiliki nilai similaritas lebih dari 50\% (Vanderpool, 2000), serta Pseudomonas sp. strain $\mathrm{J}$ dan $\mathrm{J}_{\text {duplo }}$ dengan nilai similaritas lebih dari $95 \%$ merupakan satu strain.

\section{Kesimpulan}

Berdasarkan sifat fenotip dan sidik jari protein, semua strain tersebut merupakan anggota Genus Pseudomonas. Pseudomonas sp. strain $\mathbf{J}$ dan $\mathrm{J}_{\text {duplo }}$ merupakan satu strain.

\section{Daftar Pustaka}

Burden, D.W. and Whitney, D.B. 1995. Biotechnology Protein to PCR: A Course in Strategies \& Lab. Techniques. Birkhauser, Boston.

Campos-Garcia, J., Esteve, A., Vasquez, R., Ramos, J.L. and Soberon-Chaves, G. 1999. The Branched-Chain Dodecyl benzene Sulfonate Degradation Pathway of Pseudomonas aeruginosa W51D Involves a Novel Route for Degradation of the Surfactant Lateral Alkyl Chain. Appl. Environ. Microbiol. 65(8): 3730-3734

Collins, C.H., Lyne, P.M. and Grange, J.M. 1989. Microbiological Methods. $6^{\text {th }} \quad$ ed. Butterwoths, London.

Galli, E., Silver, S. and Witholt, B. 1992. Pseudomonas: Molecular Biology and Biotechnology. American Society for Microbiology, Washington D.C.

Biota Vol. 12 (1), Februari 2007
Horn, J.M., Harayama, S. and Timmis, K.H. 1991. DNA Sequence Determination of the TOL Plasmid (pWWO) xyl GFS genes of Pseudomonas putida: Implications for the Evolution of Aromatic Catabolism. Mol. Microbiol. 5 (10): $2459-2474$.

Jerabkova, H., Kralova, B. and Nahlik, J. 1999. Biofilm of Pseudomonas C12B on Glass Support as Catalytic Agent for Continuous SDS Removal. Int. Biodet. Biodeg. 44: 233 - 241.

Jimenez, L., Breen, A., Thomas, N., Federle, T.W. and Saylor, G.S. 1991. Mineralization of Linear Alkylbenzene Sulfonate by a four member Aerobic Bacteries Consortium. Appl. Environ. Microbiol. 57 (5): 1566 - 1569.

Kahnert, A., Vermeij, P., Wietek, C., James, P., Leisinger, T. and Kartesz, M.A. 2000. The ssu locus Plays a Key role in Organosulfur Metabolism in Pseudomonas putida S-313. J. Bacteriol. 182 (10): 2869 - 2878.

Kenzaka, T., Yamaguci, N., Prapagde, B., Mikami, E. and Nasu, M. 2001. Bacterial Community Composition and Activity in Urban Rivers in Thailand and Malaysia. J. Health Sci. 47(4): 353-301.

Rahardi, B. 2002. Pemrograman Aplikasi Konstruksi Kekerabatan Taksonomi Dengan Visual $\mathrm{C}++6$.0. Skripsi. Jurusan Biologi FMIPA, Universitas Brawijaya, Malang.

Retnaningdyah, C., Samino, S., Suharjono, Doddy, I. dan Prayitno. 1999. Uji Toksisitas Akut Surfaktan Deterjen LAS dan ABS terhadap Beberapa Gastropoda Sungai. Natural 3 (2): 63-74.

Retnaningdyah, C., Samino, S., Suharjono, Hadi, M. dan Prayitno. 2001. Pengaruh Surfaktan Deterjen (ABS dan LAS) terhadap Kemampuan Regenerasi Planaria (Dugesia trigina). Natural 5: 21-26.

Schleheck, D., Lechner, M., Schonemberger, R., Suter, M.J.F. and Cook, A.M. 2003. Desulfonation and Degradation of the Disulfodiphenylethercarboxylates from Linear Alkyldipheniletherdisulfonate Surfactant. Appl. Environ. Microbiol. 69 (2): $938-944$.

Schoberl, P. 1989. Basic Principles of LAS Biodegradation. Tens. Surf. Det. 26(2): 8694.

Sembiring, L. 2002. Petunjuk Praktikum Sistematika Mikrobia S-2. Laboratorium Mikrobiologi, fakultas Biologi, UGM, Yogyakarta. 
Siguillot, J.C. dan Nguyen, M.H. 1992. Complete Oxidation of Linear Alkybenzene Sulfonate by Bacterial Communities Selected from Coastal Seawater. Appl. Environ. Microbiol. 58: $1308-1312$.

Skinner, F.A. and Lovelock, D.W. 1979. Identification Methods for Microbiologist, $2^{\text {nd }}$ ed. Academic Press, London.

Suharjono, Ardyati, T. dan Marwati, U. 2004. Seleksi Strain Bakteri Anggota Pseudomonas Pengurai LAS (Linear Alkylbenzene Silfonate) Berdasarkan Uji Potensi dan Analisis DNA Plasmid. Laporan Research Grant TPSDP. Jurusan Biologi, FMIPA, Universitas Brawijaya, Malang.

Todar, K. 2004. Pseudomonas and Its Relatives. Univ. of Wisconsin-Madison, Dept. of Bacteriology. http://www.textbookofbacteriology.net/pseud omonas.html.

Vanderpool, C.R. 2000. Bacterial Chemistry and Structure.

http://zoey.med.howard.edu/2003/immuno/38-00\%208-9AM.htm. Diakses 19 Januari 2004.
Van Ginkel, C.G. 1996. Complete Degradation of Xenobiotic Surfactants by Consortia of Aerobic Microorganism. Biodegradation 7: $151-164$.

Wackett, L. 2003. Pseudomonas putida a Versatile Biocatalyst. Nat. Biotechnol. 21 (2): 136 138.

Zarnowski, R., Eichel, J., Lewicha, T., Rozycki, H. and Pietr, S.S. 2001. Protein Fingerprinting as a Complementary Tool for the Classification of Pseudomonas Bacteria. Cell. Mol. Biol. Lett. 6 (4): $913-923$.

Zeni, C. and Caligiuri, A.S. 1992. Morphological and Ultrastructural Change Induced by sub Lethal Concentration of an Anionik Detergent on Ictalurus species Barbel Taste Buds. Microbios 69: 1 - 52 . 